\title{
Correction of Hydrate Dissociation in Shale Media via Correlation of Kim's Model
}

\author{
B. Mokhtari ${ }^{1}$, M. Enayati ${ }^{1}$ and K. Pourabdollah ${ }^{2}$ \\ 1 Lavan Island Oil Laboratory, Iranian Offshore Oil Co., Park Way, Tehran - Iran \\ 2 Chemical Engineering Department, Islamic Azad University, Shahreza - Iran \\ e-mail: mokhtari.bahram@gmail.com - pourabdollah64@gmail.com \\ * Corresponding author
}

\begin{abstract}
Résumé - Dissociation des hydrates dans les schistes bitumineux : correction de la corrélation calculée par le modèle de Kim - Les hydrates de gaz des fonds océaniques sont des substances cristallines semblables à de la glace dans lesquelles des gaz hydrocarbonés et non hydrocarbonés ayant des diamètres moléculaires spécifiques sont maintenus par des liaisons hydrogène à l'intérieur de cages rigides faites de molécules d'eau. Il a été suggéré que la libération soudaine de 1100 à $2100 \mathrm{Gt}$ de carbone causée par la dissociation de jusqu'à $10 \%$ du stock mondial d'hydrates est la cause à la fois d'une anomalie positive de l'isotope $\mathrm{C}$ et d'un réchauffement atmosphérique mondial contemporain par l'intermédiaire d'un accroissement de l'effet de serre. Le modèle de Kim suppose que, à température constante, la décomposition des hydrates de gaz peut être décrite par un processus en deux étapes: destruction du réseau hôte du clathrate à la surface d'une particule et désorption de la molécule incluse. Dans le présent article, la thermodynamique et la cinétique de la décomposition des hydrates de gaz des fonds océaniques d'après le modèle de Kim sont passées en revue, puis, à l'aide d'un réacteur d'essai en acier inoxydable et du logiciel d'acquisition de données Omega, leur corrélation avec des environnements sableux est formulée par un ajustement numérique tiré des données expérimentales. La corrélation du modèle de Kim classique suppose que la configuration de la formation des hydrates gazeux est un type d'enrobage superficiel autour d'un grain de sable. Selon le nouveau mécanisme de dissociation, une première étape utilise la chaleur de dissociation en tant que facteur contrôlant la vitesse pour exprimer la formulation du taux de dissociation corrélé. Dans la seconde étape du mécanisme, le transfert de masse est utilisé en tant que facteur contrôlant la vitesse pour déterminer un facteur de constante de vitesse modifié au lieu du facteur constant de Kim. Le coefficient de corrélation entre les résultats de l'estimation et ceux de l'expérience est supérieur à 0,98 pour des sables de tailles de grains de diamètres 85 et $216 \mu \mathrm{m}$.
\end{abstract}

\footnotetext{
Abstract - Correction of Hydrate Dissociation in Shale Media via Correlation of Kim's Model Deep-sea gas hydrates are ice-like crystalline substances in which hydrocarbon and non-hydrocarbon gases of specific molecular diameters are held by hydrogen bonding within rigid cages of water molecules. Sudden release of 1100-2100 Gt of carbon from dissociation of up to 10\% of the global hydrate reservoir has been suggested as the cause of both the $C$-isotope excursion and coeval global atmospheric warming through an enhanced greenhouse effect. Kim's model assumed that, at a constant temperature, a two-step process could describe gas hydrate decomposition, including destruction of the clathrate host lattice at the surface of a particle and desorption of the guest molecule from the surface. In this paper, first, the thermodynamics and the kinetics of gas hydrate decomposition via Kim's model in
} 
the seafloors was reviewed; then, by a stainless steel test cell reactor and Omega Data Acquisition software, their correlation to sandy environments was formulated via numerical fitting of experimental data. The correlation of the conventional Kim's model is that the configuration of gas hydrate formation as a type of surface coating around sand grains was assumed. In the first stage of new mechanism dissociation, when the rate-controlling factor is dissociation heat, the formulation of the correlated dissociation rate was expressed. In the second stage of the mechanism, when the rate-controlling factor is mass transfer, the modified rate constant factor instead of Kim's constant factor was determined. The coefficient of correlation between the results of the estimation and experiment was more than 0.98 for both 85 and $216-\mu m$ sands.

\section{INTRODUCTION}

The importance of gas hydrates as an agent for climate change has become clear over the last decade [1,2]. Methane hydrates within sediments along continental margins store huge quantities of isotopically light carbon [3].

At present, gas hydrates are stable in sediments at water depths of over $250 \mathrm{~m}$ and can form a layer up to $700 \mathrm{~m}$ thick beneath the seafloor. The stability of the hydrate layer is critically sensitive to pressure and temperature conditions within the host sediments. A rise in the bottom water temperature or a decrease in water depth cause thinning of the stable hydrate layer by dissociation to form methane gas. The light isotopic composition, large volume and environmental sensitivity of the global hydrate reservoir make it a prime candidate for a carbon source. Sudden release of carbon from dissociation of up to $10 \%$ of the global hydrate reservoir has been suggested as the cause of both the C-isotope excursion and coeval global atmospheric warming through an enhanced greenhouse effect [4-6].

Whatever the source of carbon, a trigger mechanism for rapid release is also required. Dickens et al. [7] suggested that a $5^{\circ} \mathrm{C}$ worldwide warming of oceanic bottom water could have triggered dissociation of sufficient methane hydrate to explain the carbon isotope excursion itself. Bice and Marotske [8] estimated that a temperature change of $3-5^{\circ} \mathrm{C}$ could cause catastrophic hydrate destabilization using a more sophisticated numerical ocean circulation model. However, evidence that significant bottom water warming immediately preceded the isotope excursion is limited [9-12]. Furthermore, ocean circulation modeling has yet to isolate a trigger for bottom water warming that is independent of atmospheric warming [8], making it perhaps more likely that oceanic warming acted as part of a positive feedback loop rather than an external trigger during global climate change.

The effect of gas hydrate decomposition on global change was first addressed two decades ago $[13,14]$ and continues to provoke discussion at present [15]. Three mechanisms are suggested to initiate gas hydrate decomposition in sediments.
Surface temperature increases in Polar Regions [16] and bottom water temperature increases in offshore areas [14] are expected to shift temperature at the bottom of a gas hydrate layer beyond gas hydrate stability conditions.

Pressure changes from dropping sea level [16] and rapid sedimentation [17] are expected to destabilize gas hydrate over geologic time. The release of hydrate-bound greenhouse gases (mainly methane) and subsequent oxidation into carbon dioxide in the atmosphere is hypothesized to have caused climate change on a global scale in the geologic past. Release of greenhouse gas may also impact the global carbon cycle by affecting the volume and isotopic properties of carbon reservoirs [18]. Dickens et al. [19] presented an early hypothesis concerning the importance of gas hydrate as an agent of global change.

\section{CONVENTIONAL KIM'S MODEL}

Kim developed a model to describe the kinetics of methane hydrate decomposition. This model assumed that, at a constant temperature, the following two-step process could describe gas hydrate decomposition: (a) destruction of the clathrate host lattice at the surface of a particle, and (b) desorption of the guest molecule from the surface. The above steps occur at the solid surface, not within the bulk of the solid.

For this model, Kim wrote the rate of hydrate decomposition as Equation (1):

$$
\frac{-d n_{H}}{d t}=K n_{H}
$$

where $n_{H}=$ mass of methane in gas hydrates (mole), $t=$ time of decomposition (s), $K=$ decomposition rate constant $\left(\mathrm{s}^{-1}\right)$.

\section{MODIFIED KIM'S MODEL}

Kim in 1987 expressed the temperature dependence in the form of an Arrhenius relationship as Equation (2):

$$
K=K_{0} e^{-\Delta E / R T}\left(f_{e q}-f\right)
$$


where $K=$ rate constant, $K_{0}=$ standard rate constant, $\Delta E=$ activation energy, $R=$ gas constant, $T=$ temperature, $f_{e}=$ fugacity of three-phase equilibrium (MPa), $f=$ fugacity of free gas (MPa). Also, the diameter of the particles was estimated from a force balance in the Stokes flow regime, giving a particle diameter of approximately $16 \mu \mathrm{m}$. Figure 1 shows the decomposition of gas hydrate particles.

From regression of experimental data the parameters were found to be:

$$
\text { In } K=29.4 \pm 1.9 \mathrm{~s}^{-1} \text { and } \Delta E / R=9400 \pm 545 \mathrm{~K}^{-1}
$$

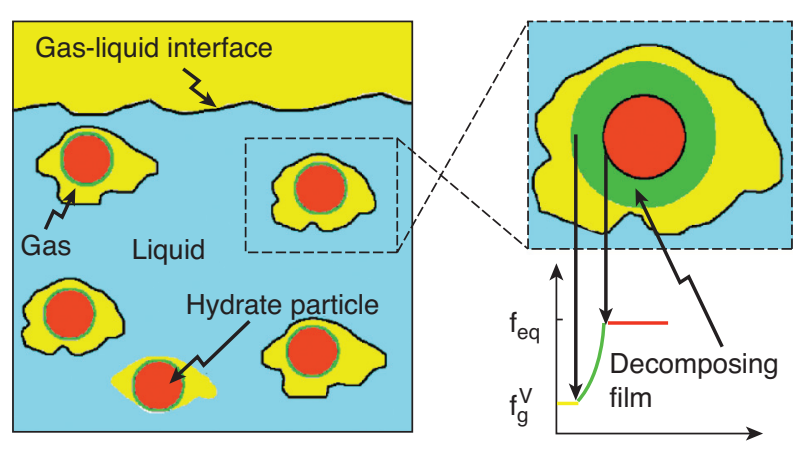

Figure 1

Kim model describes the kinetics of methane hydrate particle decomposition [20,21].

Using the geometric data and the temperature dependence data, the rate of disappearance of methane was written as Equation (3):

$$
\frac{-d n_{H}}{d t}=\left[\frac{7.44 \times 10^{11}}{\Psi \rho_{H} D_{0}}\right] e^{-9400 / T}\left(f_{e q}-f\right) n_{H}
$$

where $\Psi=$ symmetric coefficient, $\rho_{H}=$ density of hydrate particles, $D_{0}=$ diffusion constant. After that, for the estimation of the dissociation rate of gas hydrates, Kim proposed the following formula as Equation (4).

$$
\frac{-d n_{H}}{d t} k_{d} A_{s}\left(f_{e q}-f\right)
$$

In this simple model, $k_{d}=$ decomposition rate constant (mole $\left./ \mathrm{m}^{2} \mathrm{MPa} . \mathrm{s}\right), A s=$ surface area of hydrate in dissociation $\left(\mathrm{m}^{2}\right) . k_{d}$ is constant, independent of the configuration and size of gas hydrates and porous media. This is a very simple expression of driving force induced by the change in fugacities between methane in three-phase equilibrium and in free gas. A dotted curve in Figure 4 is the estimation result by Equation (4) that is shown in Figure 3. Using this model, Kim determined the rate constants for methane decomposition at different temperatures. $K$ values versus temperature are given in Table 1:

TABLE 1

Rate constants for methane hydrate decomposition

\begin{tabular}{c|c}
\hline Temperature $(\mathrm{K})$ & $K\left(\right.$ mole $\left./ \mathrm{m}^{2} \mathrm{MPa} . \mathrm{s}\right)$ \\
\hline 274.2 & 0.00756 \\
\hline 276.7 & 0.00943 \\
\hline 279.0 & 0.01530 \\
\hline 281.1 & 0.01753 \\
\hline 283.1 & 0.02299 \\
\hline
\end{tabular}

\subsection{Experimental Method}

A stainless steel test cell was used. A schematic of this test cell is shown in Figure 2. The test cell of $494 \mathrm{ml}$ internal volume was a Model 4762 constructed of 316 stainless steel and rated for a maximum pressure of 2950 psi. The cell was 2.5 inches inside diameter by 5.94 inches tall.

The test cell had one port for a RTD (Resistance Temperature Detector) probe, placed at the top of the cell through a 9/16th-inch branched fitting; the RTD allowed

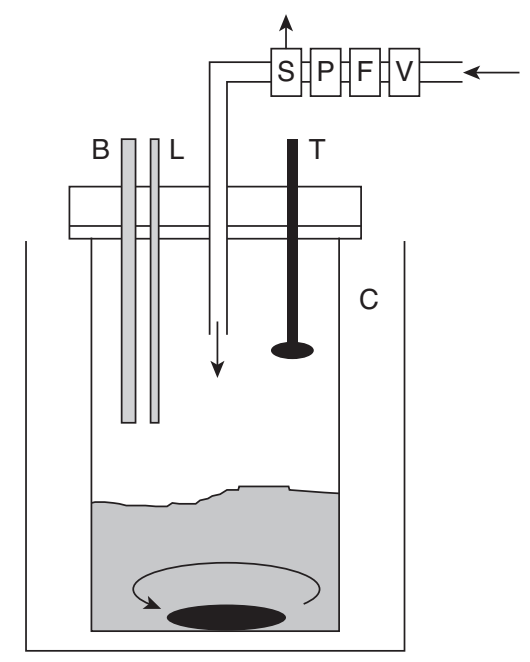

Figure 2

Schematic of hydrate reactor vessel (Autoclave). Where $B$ is borescope, $L$ is light source, $T$ is thermocouple, $S$ is safety valve, $P$ is pressure transmitter, $F$ is flow transmitter, $V$ is main valve, $C$ is water bath. 
temperature measurement during the process when heat was liberated upon hydrate formation. A pressure transducer was also mounted on the fitting and calibrated from 0-600 psig. The pressure relief valve was set to relieve at 700 psig and was fitted on one end of the 9/16th-inch branch fitting; the valve prevented overload of the pressure inside the cell.

Two 1/4-inch i.d. viewing tubes extended into the cell through two Female Nominal Pipe Thread (FNPT) ports: the short one allowed light input from a 150-watt source transmitted by a fiber optics light guide; the long one enabled the observation of hydrate formation through a camera probe inserted in it. Both viewing tubes were sealed at one end with transparent sapphire windows pressure-checked at 700 psi.

A 3-inch length of 1-1/16-inch i.d. aluminum tube on a 3 -inch length of 1-3/8-inch i.d. polycarbonate tube were put into the cell separately for tests. The tubes were drilled evenly with 3/16-inch holes around the wall to maintain contact between gas and liquid on the inside and outside of the vertically standing tubes.

A 500-ml graduated cylinder was used to measure the required distilled water. The solution was poured directly into the test cell. Then, 30 grams of standard 216- $\mu \mathrm{m}$ sand and 30 grams of standard $85-\mu \mathrm{m}$ sand were poured directly into the test cell in two separate stages. The entire pressure test cell with solution was first submerged and conditioned in a 4-gallon reservoir fitted with a stainless steel heating/cooling coil and maintained at constant temperature with a Cole-Parmer circulating bath, and then transferred to a Thermo NESLAB cooling bath for refrigeration. All the

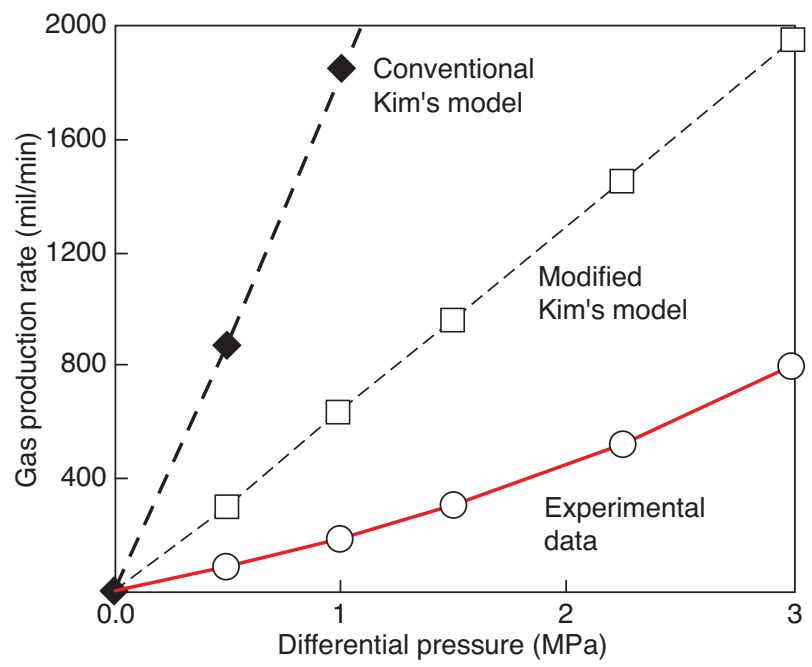

Figure 3

The result curves of experimental data (both $85 \& 216 \mu \mathrm{m}$ ), Kim's and modified Kim's models. experimental data was automatically recorded by Omega Data Acquisition software, which recorded data every 25 seconds. The results are shown in Figure 3 as the curve of experimental values.

\subsection{Result and Discussion}

The result table and curves of experimental data, modified Kim's model and conventional Kim's model are illustrated in Table 2 and Figure 3, respectively.

TABLE 2

Values of experimental data (both $85 \& 216 \mu \mathrm{m}$ ), modified and conventional Kim's models

\begin{tabular}{c|c|c|c|c}
\hline \multirow{2}{*}{$\begin{array}{c}\text { Differential } \\
\text { pressure } \\
(\mathrm{MPa})\end{array}$} & \multicolumn{4}{|c}{ Gas production rate (mil/min) } \\
\cline { 2 - 5 } & \multicolumn{2}{|c|}{ Experimental data } & Modified Kim's & $\begin{array}{c}\text { Conventional } \\
\text { Kim's model }\end{array}$ \\
\cline { 2 - 5 } & $85 \mu \mathrm{m}$ & $216 \mu \mathrm{m}$ & $\operatorname{model}(16 \mu \mathrm{m})$ & Kim's \\
\hline 0 & 0 & 0 & 0 & 0 \\
\hline 0.5 & 90 & 91 & 300 & 880 \\
\hline 1 & 190 & 188 & 630 & 1850 \\
\hline 1.5 & 310 & 310 & 950 & - \\
\hline 2.25 & 520 & 515 & 1450 & - \\
\hline 3 & 800 & 800 & 1950 & - \\
\hline
\end{tabular}

\section{THE REASONS FOR DIFFERENCES BETWEEN THE TWO MODELS}

As Figure 3 shows, there are large differences between the estimated results by Equation (4) (modified Kim's model) and experimental data. The reason for those differences can be summarized in four categories: first, the modified Kim's model was based on a two-phase decomposition mechanism while, as described in Figure 4, hydrate layer dissociation among sand grains is based upon a three-phase mechanism. The mechanism of hydrate dissociation in shale media is a three-phase process in which irreducible water (formed from hydrate decomposition) accumulates on hydrate particles' surface, not among grains. Second, the Arrhenius equation is for some systems without diffusion and thermally resistant. When the particle diameter increases, diffusion resistance increases and the precision of the Arrhenius equation will decrease. $K d$ in the modified Kim's equation (16- $\mu$ m grains) will not fit to experimental data $(85 \mu \mathrm{m}$ and $216 \mu \mathrm{m})$. Third, Kim assumed the cross-section difference of hydrate particles versus time is zero. This assumption is acceptable for tiny hydrate particles $(16 \mu \mathrm{m})$ but in bigger grains, the cross-section increases and therefore, cross-section difference versus time will not be negligible. This crosssection difference should affect the mass transfer or dissociation rate. 

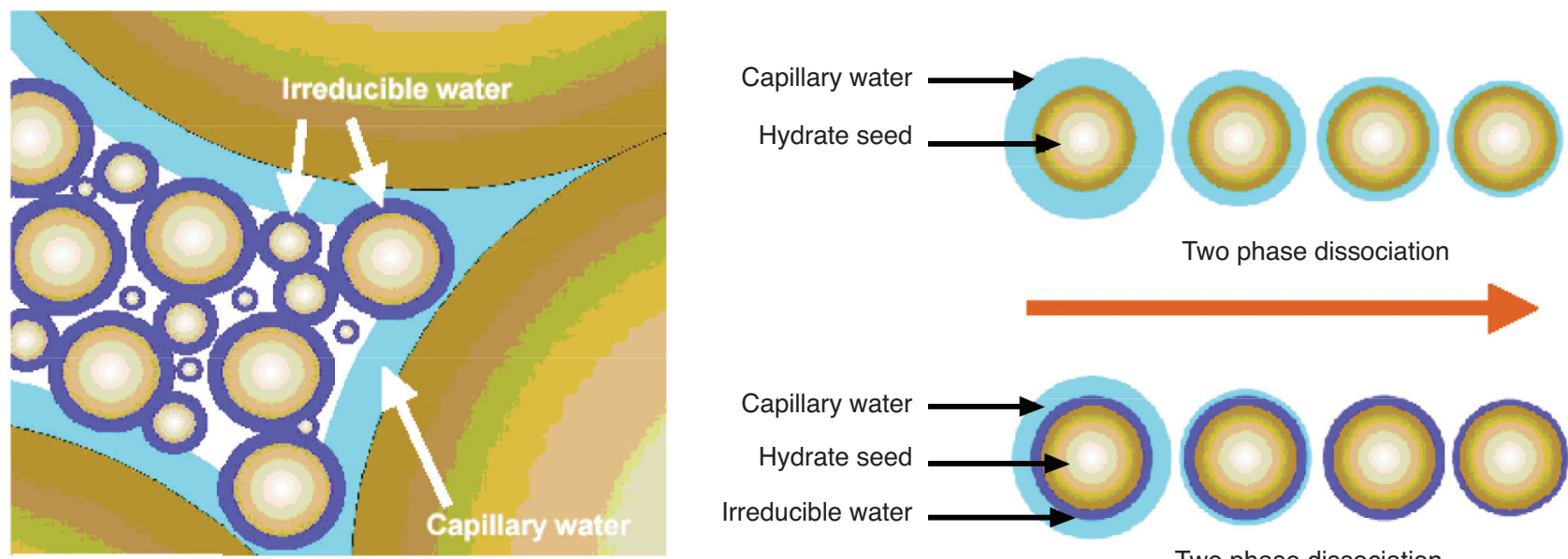

Two phase dissociation

Figure 4

The model of gas hydrate dissociation in porous shale media [23, 24].

Fourth, the diffusion coefficient in gas systems is a function of temperature. When the diameter of hydrate particles increases, the fugacity and temperature through the diffusion path are changed. These changes have more intensity in bigger sand diameters. For this reason, in bigger particles, the diffusion coefficient is not constant along the diffusion path, while in the modified Kim's model, this coefficient was constant for tiny hydrate particles.

\section{NEW CORRELATION ASSUMPTIONS}

Because there are large differences between the estimated results by Equation (4) and experimental data, a correlation to the modified Kim's model was developed for simulating hydrate dissociation in porous shale media. Figure 4 illustrates two models of gas hydrates in shale media.

It was assumed the configuration of gas hydrate depends on the surface coating around sand grains. We propose that hydrate dissociation in sandy permafrost consists of a twostage, three-phase process:

- in the first stage of dissociation, when the rate-controlling factor is dissociation heat, the formulation of the correlated dissociation rate is expressed in Equation (5) by data fitting from Figure 3. Data fitting was carried out via the trial and error method in Excel:

$$
\frac{-d n_{H}}{d t}=k\left(S_{H}\right)^{0.474}(D)^{0.822}\left(P_{e}-P\right)^{1.21}
$$

where $S_{H}=$ saturation of gas hydrates in pore space, $D=$ diameter of sand grain $(\mu \mathrm{m}), P_{e}=$ pressures in three-phase equilibrium (MPa), $P=$ pressures in the experiment (MPa). For $S_{H}$ measuring in sand or shale media, we changed this factor to a measurable parameter like $A \times a H$. This replacement is shown in Equation (6). Pressures in three-phase equilibrium according to the hydrate structure were estimated via standard methane three-phase diagrams. In this experiment, equilibrium temperature was $8^{\circ} \mathrm{C}$ and next, data fitting in standard diagrams was done. The pressure in three-phase equilibrium was $4.8 \mathrm{MPa}$;

- in the second stage of dissociation, when the ratecontrolling factor was mass transfer, the rate constant factor $k$ ' instead of $k$ was determined.

Finally, the comprehensive formulation of gas hydrate dissociation in porous media can be expressed as Equation (6):

$$
\frac{-d n_{H}}{d t}=k^{\prime}\left(A \times a_{H}\right)^{0.474}(D)^{0.822}\left(P_{e}-P\right)^{1.21}
$$

where $k^{\prime}=$ modified rate constant, $A=$ reverse of sandhole diameter $\left(\mu \mathrm{m}^{-1}\right), a_{h}=$ thickness of hydrate coating around sand grain that was observed via microscope observation. Via microscope scaling, the hydrate coating thickness around sand grains was calculated. Figure 5 shows the microscopic observation of $216-\mu \mathrm{m}$ sands for estimating the thickness of the hydrate coating around sand grains. As this figure shows, in this experiment, $a_{H}$ was $100 \mu \mathrm{m}$ on average, $A$ was $(120 \mu \mathrm{m})^{-1}$ and grain diameter was $216 \mu \mathrm{m}$. According to this picture, $S_{H}$ was 0.80 . Similarly, $S_{H}$ for $85-\mu \mathrm{m}$ grains media was calculated as 0.78 . 

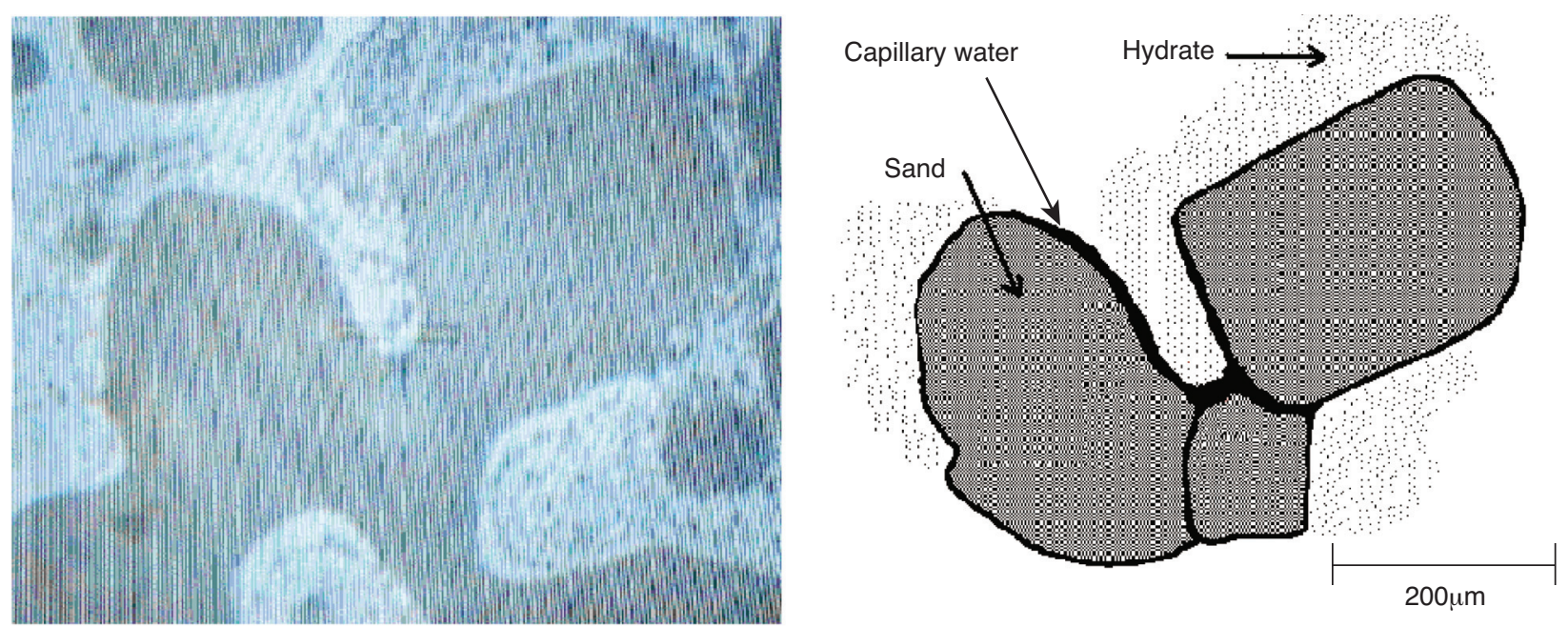

Figure 5

Microscopic picture and schematic illustration of in situ macroscopic observation of hydrate coating in sandy media (216- $\mu \mathrm{m}$ grains).

If the rate-controlling factor for gas hydrate dissociation is defined and some parameters are obtained by experiments, more reasonable results of estimation can be obtained by using Equations (5) or (6). The correlation coefficient between estimated and experimental results was more than 0.98 . This might bring better correlation between simulation and production tests for gas hydrates from marine shale sediments.

\section{CONCLUSIONS}

Kim developed a model at a constant temperature to describe the kinetics of methane hydrate decomposition in a two-step process. However, there are large differences between the estimation results by Kim's dissociation equation and experimental results in sandy environments when sand particle sizes are $85 \& 216 \mu \mathrm{m}$. The correlation of the conventional Kim's model is that the configuration of gas hydrate formation was assumed to be a type of surface coating around sand grains. In the first stage of dissociation, when the rate-controlling factor is dissociation heat, the formulation of the correlated dissociation rate was expressed. According to the microscopic observation, the coating thickness of gas hydrates was defined and saturation of hydrate was obtained. In the second stage of dissociation, when the rate-controlling factor was mass transfer, the rate constant factor $k$ ' instead of $k$ was determined. Data fitting was carried out via trial and error in Excel and a new formula, as in Equations (5) and (6), was extracted to correct both conventional and modified Kim's models in sand media with relatively larger grains. The coefficient of correlation between the results of the estimation and experiment was more than 0.98 for both $85-\& 216-\mu \mathrm{m}$ grains. The source of differences between the modified Kim's model and experimental data was described as four categories: the modified Kim's model was based on a two-phase decomposition mechanism while hydrate layer dissociation among sand grains is based upon a three-phase pattern; when the diameter of the particles increases, diffusion resistance also increases and therefore, the precision of the Arrhenius equation decreases; Kim assumed the cross-section difference of hydrate particles versus time is constant but cross-section difference versus time will not be negligible in larger grains; in bigger particles the diffusion coefficient is not constant along the diffusion path.

\section{REFERENCES}

1 Dickens G.R. (2001) The potential volume of oceanic methane hydrates with variable external conditions, Org. Geochem. 32, 1179-1193.

2 Nisbet E.G. (2002) Have sudden large releases of methane from geological reservoirs occurred since the Last Glacial Maximum, and could such releases occur again? Philos. T. Roy. Soc. A 360, 581-607.

3 Kvenvolden K.A., Lorenson T.D. (2001) The global occurrence of natural gas hydrate, AGU Geophys. Monogr. Ser. 124, 3-18.

4 Zachos J.C., Rohl U., Schellenberg S.A., Sluijs A., Hodell D.A., Kelly D.C., Thomas E., Nicolo M., Raffi I., Lourens L.J., McCarren H., Kroon D. (2005) Rapid acidification of the ocean during the Paleocene-Eocene thermal maximum, Science $\mathbf{3 0 8}$, 1611-1615.

5 Dickens G.R., Castillo M.M., Walker J.C.G. (1997) A blast of gas in the latest Paleocene: simulating first-order effects of massive dissociation of oceanic methane hydrate, Geology $\mathbf{2 5}$, 259-262. 
6 Renssen H., Beets C.J., Fichefet T., Goosse H., Kroon D. (2004) Modeling the climate response to a massive methane release from gas hydrates, Paleoceanography 19, doi:10.1029/2003 PA000968.

7 Dickens G.R., O’Neil J.R., Rea D.K., Owen R.M. (1995) Dissociation of oceanic methane hydrate as a cause of the carbon isotope excursion at the end of the Paleocene, Paleoceanography 10, 965-971.

8 Bice K.L., Marotzke J. (2002) Could changing ocean circulation have destabilized methane hydrate at the Paleocene/Eocene boundary? Paleoceanography 17, doi:10.1029/2001PA000678.

9 Zachos J., Pagani M., Sloan L., Thomas E., Billups K. (2001) Trends, rhythms, and aberrations in global climate $65 \mathrm{Ma}$ to present, Science 292, 686-693.

10 Dickens G.R. (2003) Rethinking the global carbon cycle with a large, dynamic and microbially mediated gas hydrate capacitor, Earth Planet. Sc. Lett. 213, 169-183.

11 Thomas D.J., Zachos J.C., Bralower T.J., Thomas E., Bohaty S. (2002) Warming the fuel for the fire: evidence for the thermal dissociation of methane hydrate during the Paleocene-Eocene thermal maximum, Geology 30, 1067-1070.

12 Tripati A., Elderfield H. (2005) Deep-Sea Temperature and Circulation Changes at the Paleocene-Eocene Thermal Maximum, Science 308, 1894-1898.

13 MacDonald G.J. (1982) The Long-term Impacts on Increasing Atmospheric Carbon Dioxide Levels, Ballinger, Cambridge, MA.

14 Chamberlain J.W., Foley H.M., MacDonald G.J., Ruderman M.A. (1983) Climate effects of minor atmospheric constituents, Oxford Univ. Press, New York.
15 Brewer P.G. (2000) Gas hydrates and global climate change, Ann. N.Y. Acad.Sci. 912, 195-199.

16 MacDonald G.J. (1990) Role of methane clathrates in past and future climates, Climatic Change 16, 247-281.

17 Kvenvolden K.A., Barnard L.A. (1983) Hydrates of natural gas in continental margins, Am. Assoc. Pet. Geol. Mem. 34, 631-640.

18 Kvenvolden K.A. (1988) Methane hydrates and global climate, Global Biochem. Cycl. 2, 221-229.

19 Dickens G.R., O’Neil J.R., Rea D.K., Owen R.M. (1995) Dissociation of oceanic methane hydrate as a cause of the carbon isotope excursion at the end of the Paleocene, Paleoceanography 10, 965-971.

20 Clarke M.A., Bishnoi P.R. (2000) Determination of the intrinsic rate of ethane gas hydrate decomposition, Chem. Eng. Sci. 55, 4869-4883.

21 Mokhtari B., Kazempour M. (2007) Study of Kim Model for Hydrates Dissociation Mechanism and Prediction of DeepSea Gas Hydrates Bubbling as the Function of Global Warming, 7th Student Chemical Engineering, Shiraz University, November 2007.

22 Mokhtari B., Razavi S.A., Kazempour M., Enayati M. (2007) Dissociation of Deep-Sea Gas Hydrates and Global Atmospheric Warming, 1st Iranian Thermodynamic Conference, Esfahan University, Esfahan, Iran, November 2007.

23 Mokhtari B. (2007) Gas Hydrate in Gas Lift, PhD thesis, International Ecoenergy Academy, Baku, Azerbaijan Republic.

Final manuscript received in December 2008 Published online in April 2009 or distributed for profit or commercial advantage and that copies bear this notice and the full citation on the first page. Copyrights for components of this work owned by others than IFP must be honored. Abstracting with credit is permitted. To copy otherwise, to republish, to post on servers, or to redistribute to lists, requires prior specific permission and/or a fee: Request permission from Documentation, Institut français du pétrole, fax. +33147527078 , or revueogst@ifp.fr. 


\section{APPENDIX}

To complete the model, it is necessary to express the particle area as a function of the moles of hydrate. Making the following assumptions does this:

- a) the gas hydrate is invariant in composition and contains $n_{h}$ moles of guest per unit volume, and

- b) all particles in the reactor have the same volume $V_{p}$ as a result of the agitation regime before decomposition and a uniform decomposition rate. Therefore:

$$
\begin{gathered}
n_{H}=\rho_{H} V \\
V_{t}=n_{P} V \\
n_{H}=\rho_{H} n_{P} V_{P} \rightarrow n_{P}=\frac{n_{H}}{\rho_{H} V_{P}} \\
\rightarrow V_{P}=\frac{n_{H}}{\rho_{H} V_{P}}
\end{gathered}
$$

- a) The number of particles in the reactor does not change with time,

- b) the particles may be considered spherical:

$$
\begin{gathered}
V_{P}=\frac{4}{3} \pi\left(\frac{D_{0}}{2}\right)^{3} \rightarrow V_{P}=\frac{\pi}{6} D_{0}^{3} \\
\rightarrow D_{0}=\left(\frac{6}{\pi} V_{P}\right)^{1 / 3}
\end{gathered}
$$

- c) in all the experiments, the particles have the same diameter immediately before decomposition. With the above assumptions, the number of particles at time equals zero can be found by Equations (7-10):

$$
\begin{gathered}
n_{P}=\frac{n_{H}}{H\left(\frac{\pi}{6} D_{0}^{3}\right)} \\
A_{P}=\frac{1}{\Psi} 4\left(\frac{D_{0}}{2}\right)^{2} \rightarrow A_{P}=\frac{1}{\Psi} \pi D_{0}^{2} \\
A_{P}=\frac{1}{\Psi}\left(\frac{6}{\pi} V_{P}\right)^{2 / 3} \rightarrow A_{P}=\frac{1}{\Psi} \pi^{1 / 3}\left(6 V_{P}\right)^{2 / 3} \\
A_{P}=\frac{1}{\Psi} \pi^{1 / 3}\left[6\left(\frac{n_{H}}{\rho_{H} n_{P}}\right)\right]^{2 / 3}
\end{gathered}
$$

This gives the total surface area as Equations (11-17):

$$
\begin{gathered}
A_{S}=n_{P} A_{P} \\
A_{S}=n_{P} \frac{1}{\Psi} \pi^{1 / 3}\left[6\left(\frac{n_{H}}{\rho_{H} n_{P}}\right)\right]^{2 / 3}=\frac{1}{\Psi}\left(\pi n_{P}\right)^{1 / 3}\left(6 \frac{n_{H}}{\rho_{H}}\right)^{2 / 3} \\
\frac{-d n_{H}}{d t}=K_{d} A_{S}\left(f_{e q}-f\right) \\
\frac{-d n_{H}}{d t}=K_{d} \frac{1}{\Psi}\left(\pi_{n_{P}}\right)^{1 / 3}\left(6 \frac{n_{H}}{\rho_{H}}\right)^{2 / 3}\left(f_{e q}-f\right)
\end{gathered}
$$$$
\frac{-d n_{H}}{d t}=\frac{1}{\Psi} K_{d} \pi^{1 / 3}\left(6 \frac{n_{H}}{\rho_{H} V_{H}}\right)^{1 / 3}\left(6 \frac{n_{H}}{\rho_{H}}\right)^{2 / 3}\left(f_{e q}-f\right)
$$

$$
\begin{aligned}
& \frac{-d n_{H}}{d t}=\frac{1}{\Psi} K_{d} \pi^{1 / 2}\left(\frac{n_{H}}{\rho_{H}}\right)^{1 / 3}\left(\frac{1}{\frac{\pi}{6} D_{0}^{3}}\right)^{1 / 3}\left(\begin{array}{c}
n \\
\rho_{H}
\end{array}\right)^{2 / 3} \\
& \frac{-d n_{H}}{d t}=\frac{1}{\Psi} K_{d}\left(\frac{n_{H}}{\rho_{H}}\right)\left(\frac{6}{D_{0}}\right)\left(f_{e q}-f\right)
\end{aligned}
$$
(19):

Rearranging the above equations gives Equations (18) and

$$
\begin{gathered}
K=\frac{1}{\Psi} K_{d}\left(\frac{6}{\rho_{H} D_{0}}\right)\left(f_{e q}-f\right) \\
\frac{-d n_{H}}{d t}=K n_{H}
\end{gathered}
$$

